\title{
Correlation between Body Mass Index to Hypertension in A Rural Area in East Java
}

\author{
Hubungan Indeks Massa Tubuh terhadap Hipertensi pada Sebuah Daerah Pedesaan di Jawa
} Timur

\author{
Alvin Hartanto Kurniawan ${ }^{1}$, Benedictus Hanjaya Suwandi ${ }^{1}$, Dicky Teguh Prakoso ${ }^{1}$, \\ Reynaldy Cliftianto Moksidy ${ }^{1}$, Irma Talitha ${ }^{1}$, Maharani Kartika Anggraeni ${ }^{1}$, Danang \\ Zulkifli ${ }^{2}$ \\ ${ }^{1}$ Faculty Of Medicine, Airlangga University; General Practitioner in Community Health Center of Ngronggot, Nganjuk, East \\ Java \\ ${ }^{2}$ General Practitioner in Community Health Center of Ngronggot, Nganjuk, East Java
}

DATA OF ARTICLE:

Received: 26 Oct 2020

Reviewed: 05 Nov 2020

Revised: 01 Dec 2020

Accepted: 05 Dec 2020

*CORRESPONDENCE:

alvinhartanto@yahoo.co.id

DOI:

10.18196/mmjkk.v21i1.7385

TYPE OF ARTICLE:

Research
Abstract: Hypertension is one of the most common diseases in primary health facilities. Hypertension increasing problem in developed and developing countries is obesity which is a risk factor for metabolic disease. However, research related to these two diseases in rural areas is still limited. Therefore, this study focuses on the relationship between Body Mass Index (BMI) and blood pressure in rural areas. This type of research is an observational study with cross-sectional in the outpatient unit of Puskesmas Ngronggot for 1 month. Patient categories were included patients aged $>18$ years with Systolic Blood Pressure (SBP) $\geq 140$ or Diastolic Blood Pressure (DBP) $\geq 90$ or a history of hypertension medication. The results were calculated using the Spearman correlation test. This study was followed by 201 participants with a distribution of $65.7 \%$ female and $34.3 \%$ male, and a median age of 59 years. Research shows that participants who are overweight and obese account for more than $60 \%$. The results of the Spearman test showed that BMI had a statistically significant correlation with SBP $(p=0.029)$, DBP $(p=0.016)$, and Mean Arterial Pressure (MAP) $(\mathrm{p}=0.008)$. In conclusion, BMI has a positive correlation with blood pressure, and obesity is prevalent in rural population.

Keywords: hypertension; Body Mass Index; obesity; rural areas

Abstrak: Hipertensi merupakan salah satu penyakit paling banyak di fasilitas kesehatan primer. Selain hipertensi, masalah yang meningkat di negara maju dan berkembang adalah obesitas yang menjadi faktor risiko terhadap penyakit metabolik. Akan tetapi, penelitian terkait dua penyakit tersebut di daerah pedesaan masih sedikit. Oleh karena itu, penelitian ini fokus pada hubungan antara Indeks Massa Tubuh (IMT) dengan tekanan darah pada orang-orang di perdesaan. Jenis penelitian ini adalah penelitian observasi dengan cross-sectional di unit rawat jalan Puskesmas Ngronggot selama 1 bulan. Kategori pasien yaitu pasien inklusi berusia $>18$ tahun dengan tekanan darah sistol (TDS) $\geq 140$ atau tekanan darah diastole (TDD) $\geq 90$ atau adanya riwayat pengobatan hipertensi. Hasil dihitung menggunakan uji korelasi Spearman. Penelitian ini diikuti oleh 201 peserta dengan distribusi $65.7 \%$ perempuan dan 34.3\% laki-laki, serta median usia 59 tahun. Penelitian menunjukkan bahwa peserta yang overweight dan obesitas berjumlah lebih dari 60\%. Hasil uji Spearman menunjukkan bahwa IMT berkorelasi signifikan dengan TDS ( $p=0.029)$, TDD ( $p=0.016)$, dan MAP ( $p=0.008)$. Kesimpulan, IMT berkorelasi positif terhadap tekanan darah, dan obesitas ditemukan banyak di populasi daerah pedesaan.

Kata kunci: hipertensi; Indeks Massa Tubuh; obesitas; daerah pedesaan 


\section{INTRODUCTION}

Hypertension is one of the most common encountered problems in primary health care. ${ }^{1}$ Its prevalence has reached about 1 billion worldwide while it is also predicted that the number will get as high as 1.56 billion worldwide by $2025^{2,3}$ Hypertension is already known as the main contributing factor to stroke and heart disease. It also correlates with other diseases, including heart failure, impaired renal function, retinal haemorrhage, and peripheral vascular disease. Therefore, hypertension has yielded a mortality rate of 9.4 million per year worldwide. 3,4 Fortunately, this increasing prevalence could be treated and prevented by antihypertensive drugs, lifestyle modification and risk factor reduction. However, these approaches sometimes do not work because on the one hand, patients are apprehensive and incompliant on their therapy and its complication. On the other hand, clinicians need a better update on antihypertensive drugs. Additionally, modifiable risk factors such as smoking, and obesity are often forgotten. ${ }^{1,5}$

Obesity is another problem that has been massively increasing in developed and even more in developing countries. Obesity has also been recognized as a major contributing factor to metabolic diseases such as diabetes mellitus, dyslipidaemia, and hypertension. ${ }^{6}$ Framingham studies found higher systole and diastole blood pressure in the overweight population compared to normal Body Mass Index (BMI) population, while decreased body weight will yield reduced blood pressure either systole or diastole. ${ }^{6,7} \mathrm{It}$ is also said that younger adults aged below 35 years old with a BMI of more than $30 \mathrm{~kg} / \mathrm{m}^{2}$ or obesity had five times higher risk of hypertension than normal BMI, while population below 55 years old also correlated positively. ${ }^{6}$

In recent years, studies had focused on more detailed factors, such as environmental factors and lifestyle factors that distinguish between the hypertension population that lived in the rural and urban areas. ${ }^{8}$ These two areas have different characteristics that will also generate a different number of prevalence and risk factors in hypertension. ${ }^{9}$ However, studies about this characteristic are still limited particularly its correlation between BMI and hypertension in Indonesia, where hypertension and rural areas are both quite prevalent. ${ }^{10}$

Therefore, this study aims to correlate between body mass index, one of the main contributing factors of metabolic disease, and hypertension in a rural area condition. We have a hypothesis that body mass index correlates with blood pressure in this population.

\section{MATERIAL AND METHOD}

This study was an observational analytic, cross-sectional, single-site study that aimed to investigate the association between body mass index and blood pressure in rural area populations. The study was performed from September $15^{\text {th }}$ to October $15^{\text {th }} 2019$ in outpatients at Community Health Care of Ngronggot, Nganjuk, East Java, Indonesia. Participants in this study were all hypertension patients that come to the outpatient clinic of this community health care. Inclusion criteria including age above 18 years old, Systole Blood Pressure (SBP) $\geq 140$ and/or Diastole Blood Pressure (DBP) $\geq 90$, or with a history of routine consumption of the antihypertensive drug. Exclusion criteria include patients' refusal to be included in this study, patients did not want to be examined, or patients unable to be examined for either anthropometry data or blood pressure data.

Variable data that was used in this study are age, gender, SBP, DBP, body height, and body weight. Mean Arterial Pressure (MAP) was obtained by calculating $[((2 \times \mathrm{DBP})+\mathrm{SBP}) / 3] \mathrm{in} \mathrm{mmHg}$. Body mass index was obtained with calculation of body weight $[\mathrm{kg}] /$ (body height $[\mathrm{m}]) .{ }^{2}$ Then, participants will be divided into four groups by their body mass index. Underweight for BMI < 18.5, normal for BMI 18.5 to 25 , overweight for BMI 25 to 30 , and obese for BMI more than 30.

The materials for this study are sphygmomanometer to measure blood pressure, stature meter to measure body height and scale for body weight. This study will be conducted for one time only for each patient without follow up.

For statistical analysis, data analyses were conducted using Statistical Package for Social Sciences (SPSS) V25.0 for Windows. Descriptive statistics were used to describe demographic data such as age, gender, body mass index, body mass index group, SBP, DBP, and MAP. Correlation between body mass index and SBP, DBP, and MAP was performed with the Spearman test. A $p$-value of less than 0.05 was considered statistically significant for the test. 
This study was conducted with the approval from the ethical board and head of the community health centre of Ngronggot. Informed consent was obtained for every patient that agreed to participate in this study.

\section{RESULTS}

The study was performed from September $15^{\text {th }}$ to October $15^{\text {th }} 2019$ in outpatients at Community Health Care of Ngronggot, Nganjuk, East Java, Indonesia. Participants in this study were all hypertension patients that come to the outpatient clinic of this community health care aged $>18$ years old with hypertension. In this study, 201 participants met the criteria to be included in the study. For gender characterization, there were 132 (65.7\%) female and 69 (34.3\%) male participants, as shown in Table 1. According to BMI cutoffs recommended by WHO, the most prevalent status was overweight, which accounted for 85 (42.3\%) patients, followed by normal BMI, obesity, and underweight, 75 (37.3\%), 30 (18.4\%), and 4 (2\%) patients, respectively, as shown in Table 2 . The median age of patients that participated in this study was 59 years old (ranged between 28 and 89).

For blood pressure, the research focused on SBP, DBP, and MAP. The mean and standard deviation for SBP was 159.85 (SD = 1.236), for DBP was 92.09 (SD = 0.748), and for MAP was $114.61(S D=0.778)$. Additionally, the mean BMI for our participants was 26.38 (SD = 5.132). These characteristics were summarized in Table 3.

The correlation using the Spearman rank-order test was used to investigate any association between BMI and SBP, DBP, and MAP. The result of the test showed that BMI was found to have a statistically significant association with all blood pressure parameters, including SBP $(p=0.029), \operatorname{MAP}(p=0.008)$, and DBP (0.016). All these correlations are summarized in Table 4.

Table 1. Distribution of Participants Based on Sex

\begin{tabular}{lll}
\hline Sex & Frequency & Percentage \\
\hline Female & 132 & $65.7 \%$ \\
Male & 69 & $34.3 \%$ \\
\hline
\end{tabular}

Table 2. Distribution of Participants Besed on BMI Classification

\begin{tabular}{cccc}
\hline BMI Class & Frequency & Percentage & $\begin{array}{c}\text { Cumulative } \\
\text { Percentage }\end{array}$ \\
\hline Underweight & 4 & $2.0 \%$ & $2 \%$ \\
Normal & 75 & $37.3 \%$ & $39.3 \%$ \\
Overweight & 85 & $42.3 \%$ & $81.6 \%$ \\
Obese & 37 & $18.4 \%$ & $100 \%$ \\
\hline
\end{tabular}

Table 3. The Mean of Blood Pressure and Body Mass Index

\begin{tabular}{lcc}
\hline & Mean & Standard Deviation \\
\hline Systole Blood Pressure & 159.85 & \pm 1.236 \\
Diastole Blood Pressure & 92.09 & \pm 0.748 \\
Mean Arterial Pressure & 114.61 & \pm 0.778 \\
Body Mass Index & 26.38 & \pm 5.132 \\
\hline
\end{tabular}


Table 4. Correlation between Body Mass Index and Blood Pressure Using Spearman Rank Test

\begin{tabular}{lcc}
\hline & $p$ & Correlation Coefficient \\
\hline Systole Blood Pressure & 0.029 & 0.154 \\
Diastole Blood Pressure & 0.016 & 0.170 \\
Mean Arterial Pressure & 0.008 & 0.188 \\
\hline
\end{tabular}

\section{DISCUSSION}

This study was performed at the Community Health Center of Ngronggot, which located in Nganjuk, East Java a district where poverty was accounted for $60 \%$ of its society. Ngronggot itself, one of the subdistrict in Nganjuk, East Java only has one primary health care which is our centre. In Ngronggot, it is noted that the prevalence of hypertension was found relatively high, about $80 \%$ of every examined blood pressure. While obesity, which was still an ignored problem health, was also found relatively high, about $25 \%{ }^{11}$ Therefore, we found that Ngronggot is a rural sub-district that fitted to be studied.

In this study, we found that BMI has a positive correlation that was statistically significant even though it was not strong toward SBP, DBP, and MAP on our adult population. This finding is consistent with several studies that also showed that BMI had a positive correlation to hypertension. In Italia, Longevity Check-Up 7+ Study showed a similar result which is BMI has a positive association with hypertension and became a significant risk factor on both systole and diastole blood pressure. ${ }^{12}$ As well as a study in China that included 8940 adults and showed obesity has a significant association towards not only hypertension but also dyslipidaemia and diabetes mellitus type $2 .{ }^{13}$ In Japan, a study was conducted in a rural area, Shimane, found that a significant positive correlation between increased body mass index and severity of hypertension. ${ }^{8}$ A study from Mali, a developing country in Africa, also showed that obesity and overweight were important risk factors because of their correlation towards hypertension severity and elevation of systole and diastole blood pressure. ${ }^{14}$

In overweight and obese individual, some factors may explain their association with hypertension. Increased body mass index will also increase body weight which will result in elevation of the total volume of body fluid and peripheral resistance (followed by hyperinsulinemia, cell membrane disruption, and hyperactivation of renin-angiotensin system). ${ }^{13}$ Increased BMI also means that there is an accumulation of excessive body fat, which is a major risk factor in hypertension even though the exact mechanism has not been understood clearly. It is presumed that there is a role of inflammation process plays in hypertension that resulted from fat cells by being sensitive to lipolysis and produce higher inflammatory cytokines. If this process continues, it will not only progress to more severe hypertension but also result in end-organ damage. Additionally, increased adipose tissue will release various adipokines, which is associated with decreased nitrite oxide production, an important substance to control vascular tone and to suppress the proliferation of vascular smooth muscle..$^{12}$ In both obese and overweight cases, impaired renal pressure natriuresis also played a major role in hypertension. Increased body mass index will increase sodium reabsorption and disrupt renal pressure natriuresis so that it eventually will increase activation of the sympathetic nervous system and the renin-angiotensin system. In chronic obesity, there is also an alteration in kidney structure which will lead to loss of nephron function and further elevate arterial pressure..$^{15}$ In contrast, lowering blood weight will yield the opposite process by increased insulin sensitivity, demoted sympathetic nervous system activation, and the other processes which will finally lead to reduced blood pressure. ${ }^{6}$

In this study, the participants had more than $60 \%$ of excessive BMI ( $42.3 \%$ overweight and $18.4 \%$ obese), which highlighted that majority of hypertensive patients were overweight or obese. This fact was particularly important because this study was conducted in a rural area, a setting that obesity snowballs than urban areas. ${ }^{16}$ The role of obesity in the rural areas has some differences compared to patients in urban areas such as lack of physical activity, a disparity of diet, socioeconomic level, and education level. ${ }^{14}$ The other factor that is also very important is food consumption capacity is much more superior in rural areas compared to urban areas because of the different approaches of the health care system, urbanization, and modernization. It is the reason why it is essential to pay attention to obesity, especially in rural areas because of those factors mentioned above. ${ }^{16}$

This study had several advantages and aimed to investigate the association between BMI and hypertension in a rural area condition even though many of the hypertension studies focused on a new approach of therapy so that studies about hypertension and obesity in rural areas are very limited compared to urban areas. This study was also conducted in primary health care, which entirely represents majority of 
the patients in rural area. However, our study also had several limitations. The nature of this study, which was cross-sectional, could not determine the causal relationship between hypertension and BMI. Besides, this study did not include control participants which could generate more substantial and more accurate statistical results. Then, although our study was conducted in primary health care of the area, we performed a passive approach which may be more accurate if it is an active approach. Last, our study was only focused on BMI factors related to hypertension, which did not rule out other factors that could influence hypertension.

\section{CONCLUSION}

This study has shown that not only excessive BMI has a positive correlation to the elevation of blood pressure, including SBP, DBP, and MAP, but also excessive BMI was quite prevalent in hypertensive population.

\section{Acknowledgement}

The authors thank the Dean of the Faculty of Medicine, Airlangga University, and the head of the Community Health Center of Ngronggot, Nganjuk, East Java.

\section{REFERENCES:}

1. Mahajan R. Joint National Committee 8 Report: How it Differ from JNC 7. Int J Appl Basic Med Res [Internet]. 2014 [cited 2019 Oct 28 ${ }^{\text {th }}$; 4 (2): p. 61-2. Available from: https://www.ncbi.nlm.nih.gov/pmc/articles/PMC4137642/, https://doi.org/10.4103/2229-516X.136773

2. Arrey TW, Dimala CA, Atashili J, Mbuagbaw J, Monekosso GL. Hypertension, an Emerging Problem in Rural Cameroon: Prevalence, Risk Factors, and Control. Int J Hypertens [Internet]. 2016 [cited 2019 Oct 28 ${ }^{\text {th }}$ ]; 2016: 5639146. Available from https://www.ncbi.nlm.nih.gov/pmc/articles/PMC5178358/ https://doi.org/10.1155/2016/5639146

3. Wang Q, Xu L, Sun L, Li J, Qin W, Ding G, Zhang J, Zhu J, Xie S, Yu Z, Zhou C. Rural-urban difference in blood pressure measurement frequency among elderly with hypertension: a cross-sectional study in Shandong, China. J Health Popul Nutr [Internet]. 2018 [cited 2019 Oct 28 ${ }^{\text {th }}$; 37:25. Available from: https://www.ncbi.nlm.nih.gov/pmc/articles/PMC6249846/ https://doi.org/10.1186/s41043-018-0155-z

4. Singh S, Shankar R, Singh GP. Prevalence and Associated Risk Factors of Hypertension: A Cross-Sectional Study in Urban Varanasi. Int J Hypertens [Internet]. 2017 [cited 2019 Oct 28 $8^{\text {th }}$; 2017: 5491838. Available from: https://www.ncbi.nlm.nih.gov/pmc/articles/PMC5733954/, https://doi.org/10.1155/2017/5491838

5. Tjokroprawiro A, Setiawan PB, Effendi C, Santoso D, Soegianto G. Buku Ajar Ilmu Penyakit Dalam. Surabaya: Airlangga University Press. 2015.

6. Aronow WS. Association of Obesity with Hypertension. Ann Transl Med [Internet]. 2017 [cited 2019 Oct $28^{\text {th}}$ ]; 5(17): 350. Available from: https://www.ncbi.nlm.nih.gov/pmc/articles/PMC5599277/ https://doi.org/10.21037/atm.2017.06.69

7. Neter JE, Stam BE, Kok FJ, Grobbee DE, Geleijnse JM. Influence of Weight Reduction on Blood Pressure: a Meta-analysis of Randomized Controlled Trials. Hypertension [Internet]. 2003 [cited 2019 Oct 28 $8^{\text {th }}$; 42(5): 87884. Available from: https://pubmed.ncbi.nlm.nih.gov/12975389/ https://doi.org/10.1161/01.HYP.0000094221.86888.AE

8. Hamano T, Shiotani Y, Takeda M, Abe T, Sundquist K, Nabika T. Is the Effect of Body Mass Index on Hypertension Modified by the Elevation? A Cross-sectional Study of Rural Areas in Japan. Int J Environ Res Public Health [Internet]. 2017 [cited 2019 Oct 28 ${ }^{\text {th }}$; 14(9): 1022. Available from: https://www.ncbi.nlm.nih.gov/pmc/articles/PMC5615559/ https://doi.org/10.3390/ijerph14091022

9. Rush KL, Goma FM, Barker JA, Ollivier RA, Ferrier MS, Singini D. Hypertension Prevalence and Risk Factors in Rural and Urban Zambian Adults in Western Province: a Cross-sectional Study. Pan Afr Med J [Internet]. $2018 \quad$ [cited $2019 \quad$ Oct 28 $8^{\text {th }}$; $30: 97 . \quad$ Available from: https://www.ncbi.nlm.nih.gov/pmc/articles/PMC6191248/ https://doi.org/10.11604/pamj.2018.30.97.14717

10. Agustina V. Kejadian Penyakit Hipertensi Dan Indeks Massa Tubuh Pada Perempuan Yang Tinggal Di Pedesaan Dan Perkotaan. Jurnal Kesehatan Kusuma Husada [Internet]. 2019 [cited 2020 November 6 ${ }^{\text {th}}$ ]. 
10(2):127-36. Available from: http://jurnal.ukh.ac.id/index.php/JK/article/view/388 https://doi.org/10.34035/jk.v10i2.388

11. Kementerian Kesehatan Republik Indonesia. Profil Kesehatan Kabupaten Nganjuk Tahun 2017. Jakarta: Kementerian Kesehatan Republik Indonesia. 2017. https://doi.org/10.3390/nu10121976

12. Landi F, Calvani R, Picca A, Tosato M, Martone AM, Ortolani E, Sisto A, D’Angelo E, Serafini E, Desideri G, Fuga MT, Marzetti E. Body Mass Index is Strongly Associated with Hypertension: Results from the Longevity Check-Up 7+ Study. Nutrients [Internet]. 2018 [cited 2019 Oct 28 ${ }^{\text {th }}$; 10(12):1976. Available from: https://www.ncbi.nlm.nih.gov/pmc/articles/PMC6316192/ https://doi.org/10.3390/nu10121976

13. Feng RN, Zhao C, Wang C, Niu YC, Li K, Guo FC, Li ST, Sun CH, Li Y. BMI is Strongly Associated With Hypertension, and Waist Circumference is Strongly Associated With Type 2 Diabetes and Dyslipidemia, in Northern Chinese Adults. J Epidemiol [Internet]. 2012 [cited 2019 Oct 28 ${ }^{\text {th }}$; 22(4): 317-23. Available from: https://www.ncbi.nlm.nih.gov/pmc/articles/PMC3798650/ https://doi.org/10.2188/jea.JE20110120

14. Ba HO, Camara Y, Menta I, Sangere I, Sidibe N, Diall IB, Colibaly S, Keita MA, Millogo GRC. Hypertension and Associated Factors in Rural and Urban Areas Mali: Data from the STEP 2013 Survey. Int J Hypertens [Internet]. $2018 \quad$ [cited 2019 Oct 28 $8^{\text {th }}$; $2018: 6959165 . \quad$ Available from: https://www.ncbi.nlm.nih.gov/pmc/articles/PMC5828104/ https://doi.org/10.1155/2018/6959165

15. Hall JE. The Kidney, hypertension, and obesity. Hypertension [Internet]. 2003 [cited 2019 Oct 28 $8^{\text {th }}$; 41(3):625 33. Available from: https://pubmed.ncbi.nlm.nih.gov/12623970/ https://doi.org/10.1161/01.HYP.0000052314.95497.78

16. Shen C, Zhou Z, Lai S, Tao X, Zhao D, Dong W, Li D, Lan X, Gao J. Urban-rural-specific trend in prevalence of general and central obesity, and association with hypertension in Chinese adults, aged 18-65 years. BMC Public Health [Internet]. 2019 [cited 2019 Oct 28 ${ }^{\text {th }}$; 19:661. Available from: https://www.ncbi.nlm.nih.gov/pmc/articles/PMC6543650/ https://doi.org/10.1186/s12889-019-7018-4 